\title{
Paperiliiton historiaprojekti
}

\section{Tutkivat opintokerhot tekivät historiaa}

Tullessani Paperiliiton palvelukseen syksyllä 1979 oli keskeiseksi tutkimusintressikseni noussut "työväenliikkeen ongelma tässä ja nyt". Mikä yhteiskunnan kehityksessä oli ollut sellaista, joka oli tehnyt työväenliikkeelle "yhä vaikeammaksi pitää kiinni alkuperäisestä luonteestaan"? Miksi se ei enää ollut "liikettä, jonka jäsenet toimivat yhdessä yhteisten työja elinolosuhteitaan koskevien ongelmien ratkaisemikseksi ja samalla tulevat kehittäneeksi itseään 'kokonaisina' ihmisinä"? Miksi työväenliikkeen oli niin vaikea toimia "työväestön itsetiedostuksen ja itsetunnon kehittäjänä"? Miksi työväenliikkeessä toimiminen ei enää "auttanut työläisiä hahmottamaan ja jäsentämään omaa ympäristöään, ... ymmärtämään yhteiskuntaa ja omaa paikkaa siinä"?

"Työväenliikkeen ongelman tässä ja nyt" tarkasteleminen nimenomaan sivistystyön näkökulmasta saa selityksensä siitä, että olin vuosina 1977-1979 paneutunut Työväen Sivistysliiton (TSL) historian kirjoittamiseen. Tämän työn jouduin Paperiliittoon tullessani keskeyttämään, mutta toisaalta sain nyt tilaisuuden ryhtyä itse tekemään päätoimisesti työväen omaehtoista sivistystyötä. Tälle loi edellytykset Paperiliiton hallinnon huoli työväenliikkeen näköaloista.

Liiton historian kirjoittaminen ei voinut jäädä ammattitutkijan yksin suorittamaksi, vaan jäsenistö oli saatava aktiivisesti mukaan. Tä- mä johtopäätös oli vastaus siihen ongelmaan, jolle eri tavoin olin etsinyt ratkaisua aina 1960luvun lopulta lähtien: miten historiantuntija voi toteuttaa yhteiskunnallisen tehtävänsä. Paperiliitto-lehteen kirjasin ajatuksen seuraavassa muodossa: "mitä muuta tietä kuin käymällä vuoropuhelua oman väen kanssa voi historioitsija löytää juuri ne ongelmat, joiden selvittämiseen hänen ammattitaitoaan tarvitaan?" Vielä painavampi oli kuitenkin toinen perustelu, jossa haettiin yhteyttä historiantutkimuksen ja sivistystyön välille. Työväenliikkeen historian kirjoittamisen on oltava "työväenliikkeeseen järjestäytyneiden ihmisten kollektiivista toimintaa oman itsetiedostuksensa syventämiseksi. Sen ulkoiseksi muodoksi soveltuu hyvin liikkeen perinteinen opintokerhotyöskentely." Ilmeistä onkin, että yksi Paperiliiton historiahankkeen lähtökohdista on TSL:n piirissä 1970-luvun lopulla kehitellyissä, ns. suoran toiminnan nimellä kulkeneissa aktiivisen sivistystyön suunnitelmissa. Niissä oli painopiste maailmankatsomusta jäsentävässä opintotoiminnassa järejstökoulutuksen vastapainona ja toteutusvastuu sivistysliiton paikallisilla opintojärjestöillä.

Tutkivan opintokerhon idean kehittelyyn ja sen välittämiseen paperiliittolaisille käytettiin kaksi vuotta. Suunnitteluvaihe päättyi syksyllä 1981, jolloin ensimäiset kerhot aloittivat toimintansa. Tuloksena on ollut uudenlainen historiankirjoituksen muoto, jonka yksi tuotos on kirjana ilmestynyt Paperiliiton historia 
1944-86. Muita ovat (toistaiseksi) ennen muuta tutkivien kerhojen valmistamat 24 historianäyttelyä, joihin on tutustunut arviolta 30000 ihmistä. Kerhot ovat tuottaneet myös kirjoja, artikkeleita, näytelmiä, kavalkaadeja, video-ohjelmia, äänilevyn sekä puhekuoro- ja musiikkiryhmäproduktioita. Vuoden 1985 lopulla Paperiliiton historiahankkeessa toimi 40 tutkivaa kerhoa 33:ssa liiton kaikkiaan 74 ammattiosastosta. Omaa historiaansa ja perinnettään tutki siten yli 200 Paperiliiton 51000 jäsenestä.

\section{Erilainen toiminta-ajatus}

Historiahankkeen toiminta-ajatus selkiytyi joutuessani suunnitteluvaiheen aikana perustelemaan tutkivien kerhojen tärkeyttä eri paperiammattiosastoissa. "Liiton historian kirjoittaminen porukalla" oli liian etäinen ajatus ja "omien kokemusten jäsentäminen" liian käsitteellinen. Välttämättömyys kehittää omaa esitystä aina edellisen alustuksen saaman vastaanoton pohjalta tuottikin kokonaisnäkemyksen niistä asioista, jotka ovat päällimmäisinä paperiliittolaisaktiivien kokemusmaailmassa ja heidän suhteessaan työväenliikkeeseen. Vaikka tähän meni aikaa, kävi varsin pian selväksi, että tutkivien kerhojen työn oli liittyttävä paperityöläisten omiin kiinnostuksen kohteisiin, heidän itsensä tärkeinä pitämiin asioihin. Tämän johtopäätöksen tekemistä nopeuttivat ruotsalaista opintokerhotutkimusta ohjanneiden tovereiden kokemukset ja neuvot. Ruotsalaiset korostivat, että tehokkain tapa varmistaa riittävän vahva motivaatio oli antaa kerhojen itse päättää, mitä ne tutkivat.

Tämä käytännön kokemusten tuottama johtopäätös käänsi päälaelleen yhden syksyn 1979 keskeisistä ajatuksistani. Tuolloin olin hahmotellut projektia, jossa kerhot valitsisivat tutkimuskohteensa liiton historiankirjoittajan laatimaan tutkimussuunnitelmaan sisältyvien tutkimustehtävien joukosta. Nyt oli lähtökohta kokonaan toinen: jokaisen kerhon oli saatava valita tutkimuskohteensa täysin riippumatta liiton historiankirjoittajan omasta tehtäväksiannosta. Ylhäältä päin ohjautuvan projektin sijaan oli löydettävä uusi muoto. Se ei saisi hävittää hankkeen luonnetta yhtenäisenä projektina, koska ruotsalaiset kokemukset olivat osoittaneet sekä tukiorganisaation että ohjauksen välttämättömiksi. Päätösvallan oli kuitenkin säilyttävä kerhoilla.

Toiminta-ajatus oli kiteytynyt syksyllä 1981, jolloin suunnittelutyö päättyi ja historiahankkeen opintokerhovaihe alkoi. Kullakin tutkivalla kerholla on täysi vapaus valita tutkimuskohteensa. Ne päättävät myös itse, missä muodossa tuloksensa julkistavat ja mihin tarkoituk- seen niitä käyttävät. Liiton historiankirjoittajan tehtävä rajoittuu tutkimustyössä tarvittavien teknisten ja menetelmällisten valmiuksien välittämiseen. Se tapahtuu lähinnä erilaisilla lyhytkursseilla, mutta myös kerhokohtaisena ohjauksena - silloin, kun sitä toivotaan. Sisällöltään koulutus vastaa yliopistollista menetelmäopetusta, mutta muotojen osalta sitä ei ole tarvinnut sovittaa mihinkään valmiisiin malleihin. Tämä on mahdollistanut koulutuksen järjestämisen siten, että se vastaa kerhojen eteen tulleisiin ongelmiin juuri sellaisina, kuin ne käytännön työssä ovat ilmenneet. Suuri etu on ollut myös se, että liiton toimisto on voinut eri muodoissa avustaa ennen muuta lähdeaineiston kokoamisessa.

\section{Tutkimus ja toiminta}

Historiahankkeen toiminta-ajatuksen kiteytyminen tuotti siten ensimmäisen täsmällisen määreen liittohistorioitsijan työnjaolliselle tehtävälle. Vaikka hänen oman tutkimustyönsä kysymyksenasettelun täsmentymiseen kuluikin vielä toiset kaksi vuotta, olivat eräät muutkin peruslähtökohdat käyneet selviksi ensimmäisten tutkivien kerhojen aloittaessa työnsä syksyllä 1981. Yksi niistä oli uusi näkökulma tieteellisen tutkimuksen ja työläisten arkipäiväisen käytännön väliseen suhteeseen. Kyse ei ollut työläisten osallistumisesta tutkimuksen tekemiseen, ei edes heidän omista lähtökohdistaan nousevasta myötävaikutuksesta, vaan heidän omasta, itsenäisestä toiminnastaan.

Suhteessa järjestöhistorian perinteeseen olivat jo syksyn 1979 suunnitelmat olleet ohjelmallista kritiikkiä. Pitäytyminen liittohallinnon ja liiton toimiston näkökulmassa vain syventäisi "työväenliikkeen ongelmaa tässä ja nyt". Perusjärjestötaso oli siis saatava mukana. Perehtyminen paperiammattiosastojen historiikkeihin taas paljasti niiden aihepiirien rajoittuneisuuden. Teemoja oli oikeastaan vain kaksi: kamppailu paikallista työnantajaa vastaan ja osaston sisäinen toiminta. Havainnon merkitys alkoi paljastua paperiliittolaisaktiivien ja toimitsijatoverien pohdiskeluja kuunnellessa. Heitä askarrutti se, että "rivijäsenet" ajattelivat ja toimivat niin monessa suhteessa eri tavoin kuin he itse. Tavanomainen järjestöhistoria osoittautui tätä eroa syventäväksi: se on tosiasiallisti nykyisten aktiivijäsenten oman ja heidän edeltäjiensä toiminnan historiaa - toisille järjestöaktiiveille esitettynä. Tutkivat kerhot saivat tästä uuden perustelun: edustuksellisuuden periaate oli murrettava. Sen sijaan, että jotkut valittaisiin kirjoittamaan muille, oli (periaatteessa) kaikkien osallistuttava historiakuvan tuottamiseen. Vielä tärkeämpi oli toinen johtopäätös. Oli tutkittava ennen muuta sitä, mitä arkisessa elämänpiirissä yhdisti 
kaikkia paperityöläisiä, niin aktiiveja kuin rivijäseniä.

Perehtyminen ruotsalaiseen opintokerhotutkimukseen (edes sen olemassaolosta en ollut tietoinen tutkivan kerhon ideaan päätyessäni) puolestaan auttoi hahmottamaan työn historiaan kohdistuvan tutkimuksen lähtökohtia. Sekä arkkitehti Gunar Sillén ("Stiga vi mot ljuset", 1977) että kirjailija Sven Lindqvist ("Gräv där du står", 1978) olivat ruotsalaiselle toiminnalle suuntaa antaneissa kirjoissaan painottaneet, että työntekijä on asiantuntija silloin, kun tutkitaan työtä. Paperityöläisten osalta näytti siltä, että heidän työssään automaation ja rationalisoinnin myötä tapahtunut mullistus ei ollut jättänyt aikaa pohtia, mitä todella oli tapahtunut ja tapahtui jatkuvasti. Teknologiset muutokset seurasivat liian nopeasti toisiaan ja välttämättömyys puolustaa omia välittömiä etuja peitti muun alleen. Omaa työtä tutkimalla olisi kuitenkin mahdollista hahmottaa kokonaiskuvaa tapahtumassa olevasta mullistuksesta ja tätä tietä välttää tosiasiallinen alistuminen sen edessä. Löytämällä selitys sille, miksi eilisen työprosessi on muuttunut nykyisen kaltaiseksi taas olisi mahdollista ennakoida, millaista huomisen työ saattaa olla.

"Huomisen työtä" koskevista pohdiskeluista oli vain lyhyt matka ajatuksiin uudella tavoin painottuneesta ammattiyhdistytoiminnasta. Miksi pitäisi antaa muutosten "kaatua päälle", kuten jokseenkin aina näytti tapahtuvan, kun ei ollut mahdotonta pyrkiä ennakoimaan niitä? Miksi tyytyä neuvottelutilanteiden tuottaman kokemuksen pohjalta kehittyneeseen näkemykseen työnantajapuolen tavoitteista, kun sitä voitiin syventää omassakin ammattiosastossa tapahtuvalla tutkimustyöllä? Näitä ajatuksia tukivat Ruotsin Tehdastyöväenliiton käynnistämät projektit "Ute i världen" ("Maailmalla") ja "Trygga jobben" ("Turvatkaa työpaikat"). Molempien tavoitteena on ollut tuottaa tutkivien kerhojen voimin tietoa eri yritysten työllisyyteen vaikuttavista suunnitelmista ja sitä tietä lisätä ammattiosastojen mahdollisuuksia pitää puoliaan.

\section{Mikä on tärkeätä?}

Historiahankkeen suunnitteluvaiheessa selkiytyneet peruslähtökohdat hallitsevat 1981 valmistunutta Paperiliiton 75-vuotishistoriaa, "Taistojen taipaleelta". Tarkastelu painottuu ammattiosastotasolle ja teoksessa pyritään nostamaan esiin järjestötoiminnan ulkopuolelle jäänyttä paperityöläisen arkea niin työssä kuin työn ulkopuolella. Tästä huolimatta tuotti oma aatteellista ja poliittista korostava maailmankuva minulle kaksi yllätystä samana vuonana. 75-vuotisjuhlien jälkeen alkaneelle liitto- kokoukselle jätetyissä aloitteissa vaadittiin voimakkaasti vapaa-ajan ja kulttuuritoiminnan laajentamista. Aloitteissa nostettiin myös esiin ongelmia, jotka vain työläästi tai ei lainkaan voitiin ratkaista perinteisessä työehtosopimuksessa. Toisessakin yllätyksessä oli sisältönä elämäntavan problematiikan korostuminen. Järjestötoimintaan liittyi vain n. $20 \%$ niistä tutkimussuunnitelmista, jotka esitettiin syksyn 1981 tutkivien kerhojen vetäjille tarkoitetuilla kursseilla. Puolet käsitteli työn ulkopuolisen elämänalueen eri puolia ja n. 30 \% työn muuttumista.

Paperiliittolaisaktiivien kiinnostus kohdistui siten odottamaani paljon voimakkaammin liiton toiminnan lähtökohtiin ja edellytyksiin kuin sen muotoihin. Heitä askarruttivat selvästikin yhteiskunnallisen todellisuuden uudet piirteet, sen muuttunut luonne. Tähän liittyi syvä huoli työväenliikkeen perinteiden katkeamisesta ja rivijäsenten historiatietoisuuden ohuudesta. Nämä piirteet rajasivat tutkimustyöni avainajanjaksoksi viimeisen neljännesvuosisadan kehityksen. Oli kyettävä suhteuttamaan keskenään suomalaisessa yhteiskunnassa 1960-luvulla tapahtunut kulttuuris-ideologinen mullistus ja Suomessakin 1970-luvun lopulta alkaen nopeasti laajentunut kiinnostus työväenperinteeseen. Tähän tuotti lähtökohdan tutkijatoverini, historioitsija Jussi Turtola. Hän oli Kunnallisten työntekijäin ja viranhaltijain liiton historiaa tutkiessaan päätynyt keväällä 1982 luonnehtimaan kahdeksankymmentäluvun Suomea "valmiiksi" yhteiskunnaksi, eräänlaiseksi jo toteutuneeksi utopiaksi. Tuntolan työ tuotti myös ensimmäiset lähtökohdat Paperilition toiminnan ulkoisten ehtojen muuttumisen analyysille.

Syksystä 1982 alkoikin vuoden päivät kestänyt historiahankkeen seestymisvaihe. Vasta nyt koin, että ajatus työläisten oman tutkimustyön tärkeydestä kahdeksankymmentäluvun Suomessa todella meni perille. Syksyn 1979 suunnitelmien perustelut olivat nousseet enemmän sivistystyön lähtökohdista kuin suomalaisen yhteiskunnan historiallisesta analyysistä. Jos ne tuolloin olivat myös olleet kaukana paperityöläisen arkipäivästä, saatoin kolme vuotta myöhemmin jo rakentaa esim. alustukseni siten, että niiden lähtökohtana oli paperiliittolaisaktiivien oma kokemusmaailma.

Myös historiahankkeen toimintamuodot kehkeytyivät syksyyn 1983 tultaessa. Tutkivat kerhot olivat voittaneet alkuvaikeutensa ja hankkeen koulutusjärjestelmän muodot alkoivat vakiintua. Toiminta alkoi myös suuntautua Paperiliiton ulkopuolelle ja pyydetyksi alustajaksi eri työväenjärjestöjen kursseille, seminaareihin jne. lähti yhä useammin joku tutkivien kerhojen vetäjistä. Huipentuma on (toistaiseksi) ollut keväällä 1984 TVK-opistolla jär- 
jestetty kurssi, joka pani alulle "tutkivien opparien" projektin Pankkitoimihenkilöliitossa.

Paperiliiton tutkivat kerhot ovat ennen muuta osoitus työväenliikkeen perusjärjestöjen aktiivijäsenten tarpeesta määrittää omaa paikkaansa muuttuvassa yhteiskunnassa ja maailmassa. Mutta yhdessä Pankkitoimihenkilöliiton projektin ja eri järjestöissä toimivien yksittäisten tutkivien opintokerhojen kanssa Paperiliiton historiahanke kertoo yleisemmästäkin ilmiöstä: kahdeksankymmentäluvun suomalaisen ihmisen pyrkimyksestä tuottaa itse tietoa, tarpeesta välttää ajautuminen tiedonkin osalta ohjelmoidun kuluttajan asemaan. Paperiliiton hanketta luonnehtii myös se, etteivät maailmankatsomukselliset erot ole estäneet sosialidemokraatteja ja kansandemokraatteja tekemästä yhteistyötä eikä käymästä juuriin menevää keskustelua - tapahtui se sitten tutkivissa kerhoissa tai historiahankkeen koulutustilaisuuksissa. Avointen kysymysten selvittäminen ei olekaan yksilöllistä pohdiskelua, vaan kollektiivista toimintaa omien näkemysten syventämiseksi. Asiaan paneutumisen vakavuutta kuvaa näiden luottamustehtävillä kuormitettujen ihmisten kirjaa varten tuottama lähdeaineisto. Omien tutkimustehtäviensä ohessa tutkivat kerhot ovat haastatelleet minun laskuuni 147 paperityöläistä.

Paperiliiton tutkivat kerhot ovatkin haaste tutkimustyön ammattilaisille. Kyse on toiminnasta, jossa kyllä on noudatettava tieteellisen työskentelyn perusperiaatteita, mutta jossa ei silti ensisijaisesti ole kyse tiedon tuottamisesta. Päällimmäisenä on koko ajan tutkimustyön merkitys sitä tekevälle ihmiselle itselleen. $\mathrm{Pa}$ periliittolaisten lähtökohtana on heidän oma elämänpiirinsä ja elämänkäytäntönsä ja tavoitteena löytää historiantutkimuksellisesti perutellut lähtökohdat omalle toiminnalle työväenliikkeessä. Tältä osin historiahanke liittyy $\mathrm{Pa}$ periliiton laajempaan pyrkimykseen eli edellytysten luomiseen ihmisten liikkeen elpymiselle työväenliikkeen sisällä.

Historiahankkeen ja sen rinnalla toteutetun valistusprojektin käynnistäminen eivät ole pakon sanelemia toimenpiteitä. Jos asioita tarkastellaan lyhyellä aikavälillä ja perinteisiä ammattiyhdistystoiminnan mittapuita käyttäen, Paperiliitolla menee hyvin. Molempien hankkeiden todellinen lähtökohta onkin tulevaisuudessa. Ne kertovat myös pyrkimyksestä löytää uusia lähtökohtia liiton toiminta-ajatıkselle. Paperiliiton voimakas panostus aatteelliseen toimintaan on siten perusteltua nähdä ennen muuta työväenliikkeen rakenteellisen kriisin ilmentymänä. Tämän kriisin luonteen määrittämisessä taas voi ottaa lähtökohdaksi paperiliittolaisaktiivien järjestelmällisen tiedonhankinnan ja sen toistaiseksi tuottamat tulokset. Nehän kertovat, millaisina suomalaisen kapitalismin ydinalueen työläiset näkevät työväenliikkeen ongelmat.

keen rakenteellisen kriisin ilmentymänä. Tämän kriisin luonteen määrittämisessä taas voi ottaa lähtökohdaksi paperiliittolaisaktiivien järjestelmällisen tiedonhankinnan ja sen toistaiseksi tuottamat tulokset. Nehän kertovat, millaisina suomalaisen kapitalismin ydinalueen työläiset näkevät työväenliikkeen ongelmat.

\section{Tutkimusten kohteet}

Jokseenkin kaikkien tutkivien kerhojen kysymyksenasetteluissa tulee esiin paperityöläisten yhteisyyden, heidän kollektiivisuutensa mureneminen. Oli nimenomainen tutkimuskohde mikä tahansa, halutaan siis selvittää, miksi yhteenkuuluvuus ja keskinäinen solidaarisuus ovat heikentyneet. Toinen tutkiville kerhoille yhteinen piirre on ollut niiden erilaisten yhteyksien etsiminen, joita paperityöläisen elämässä työn ulkopuolella tapahtuneilla muutoksilla on ollut heidän ammatilliseen toimintaansa. Nämä teemat ovat hyvin luontevia, kun muistetaan paperiteollisuusyhdyskuntien totuttu, oikeastaan sisäänlämpiävä elämänmeno.

Paperiteollisuusyhdyskunnan muuttumisen vaikutukset ammattiosaston toimintaan ovat punaisena lankana Mäntän ja Myllykosken kerhojen tutkimuksissa. Pyhtääläisten kerho keskittyi työläisten asuinalueena toimineen kasarmikylän elämään ja kaukopääläisten kerho ammattiosaston kesänviettopaikan rakentamiseen. Tainionkoskelaisten tutkimusta jäsentää 1950- ja 1960-lukujen taitteesta alkanut mullistus eri asuntoalueilla. Jos elämänmenoa säädelleet tekijät siihen asti olivat olleet lähes jäännöksettömästi yhdyskunnan sisäisiä, ne tulivat nyt yhtä vahvasti ulkoapäin ja olivat paljossa luonteeltaan ylikansallisia. Tervakoskelaisten lähtökohtana taas ovat olleet tehtaan nykyjohdon pyrkimykset säilyttää yhtiön kansainvälinen kilpailukyky. Ne ovat nopeasti hävittämässä yhdyskunnan perinteiden molemmat keskeiset juonteet. Toisaalla on ollut tehtaan "teknillinen linja vanhoillisuuden ja vainparas-on-kyllin-hyvää -asenteen yhdistelmänä", mihin on kiinteästi liittynyt työntekijöiden korkea ammattitaito. Toisaalla taas "nurkkapatrioottisen kyläyhteisön yhteishenki". Aihettaan tervakoskelaiset lähestyvät muutaman paperityöläissuvun vaiheita tutkimalla. Sitä varten he ovat kaivaneet kirkonkirjoista esiin kaikkien tehtaalla vuosina 1818-1935 työskennelleiden henkilötiedot. 
Huoli työväen- ja erityisesti paperityöläisperinteen katoamisesta on toinen monille kerhoille yhteinen piirre. Tämä on ollut yksi niistä tekijösitä, jotka ovat saaneet tutkivat kerhot rakentamaan yleisömenestyksen saavuttaneet näyttelynsä. Suurimman valokuvakokoelman on koonnut tainionkoskelaisten kerho. On myös tuotettu lähdeaineisto osaston historiikin ja kerätty sen lisäksi mm. suuri määrä paikallista ammattisanastoa ja muuta muistotietoa.

Kaskisten tutkivan kerhon tavoitteena on ollut rakentaa siltaa paikkakunnan vanhan työväenliikkeen ja vuonna 1976 toimintansa aloittaneen sellutehtaan työläisten välille. Tässä tarkoituksessa järjestettiin paperityöläisten aloitteesta kaupungin 200-vuotisjuhlien yhteydessä paikallisen työväen kulttuuria ja historiaa esittelevä kulttuuritapahtumien sarja, Työväen viikko. Ruotsinkieliselle paikkakunnalle tulleiden suomenkielisten paperityöläisten ongelmat ovat olleet myös Kirkniemen ja osin Pietarsaaren osaston tutkivien kerhojen lähtöikohtana. Summalaisten kirjaa osastonsa vaiheista taas jäsensi paperitehtaan tulo maaseutupaikkakunnalle vuonna 1955.

Pyrkimykseen lujittaa aatteellista tietoisuutta perinnettä välittäen liittyy saumattomasti työväenliikkeen historian esiin tuominen. Useimmat tämän päivän paperityöläiset ottavat olevat olot annettuina. He eivät tiedä, että ammattiosasto työväenliikkeen osana on saanut käydä pitkän kamppailun edes nykyisten etuisuuksien ja mahdollisuuksien saavuttamiseksi. Tämän tilannearvion pohjalla nousevat useiden tutkivien kerhojen hankkeet osastonsa historian kirjoittamiseksi.

Osa kerhoista on ottanut työn oman tutkimuksensa lähtökohdaksi. Esim. kaipolalaiset tuottavat sivun kerrallaan "Paperikoneen päiväkirjaan". Hämeenlinnalaiset taas ovat paneutuneet kertakäyttöastioita valmistavien paperiliittolaisten työn muuttumiseen. He ovat toistaiseksi tuottaneet aiheestaan valokuvanäyttelyn, joka (monien muiden kerhojen näyttelyiden tavoin) on ollut esillä tehtaan lisäksi myös kaupungin/kunnan kirjastossa. Takolaiset taas lähestyvät kartonkitehtaan työn muuttumista seuraamalla seitsemän työntekijän ammattiuran kehitystä. Näistä seitsemästä sälkeestä punoutuvaan kokonaisuuteen mahtuu myös paljon oman ammattiosaston ja tamperelaisen työväenliikkeen historiaa. Tesomalaisten tutkimuksen keskipisteenä taas ovat työn sisällössä ja työn organisaatiossa tapahtuneiden muutosten vaikutukset työläisten tietoisuuteen.

Tesomalaisten tutkimushankkeella on välitön kytkentä "lattiatason työnantajapolitiikassa" 1980-luvulla näkyviin tulleisiin uusiin piirteisiin. Äänekoskelaisten ja Kuusankosken tehtaiden kuljetusosaston tutkivan kerhon hankkeella on välillisempi yhteys ajankohtaiseen ammattiyhdistystoimintaan. Äänekoskella on pyritty oman työn (yhtiön asuntorakennusosasto) historian myötä selvittämään muutoksia paperityöläisten asumisolosuhteissa. Kuusankoskella taas ovat tutkimuskohteena kuljetusteknologian kehityksen erilaiset seurausvaikutukset.

Oman erityisen ryhmänsä muodostavat paperityöläisnaisten ongelmiin paneutuvat tutkimushankkeet. Kymi-Strömbergin kolmen ammattiosaston yhteinen tutkiva kerho selvittää naisten työllisyyden kehityspiirteitä kaikilla Kuusankosken tehtailla. Takon naisjaoston tutkiva kerho taas on lähtenyt selvittämään naisten ns. vapaa-aikaan liittyviä ongelmia. Naisten erillistoimintaa on puolestaan tutkittu Kauttualla, Kemissä ja Pietarsaaressa.

Tutkimuskohteissa on syksyn 1981 ideointivaiheeseen verrattuna tapahtunut siirtymää ammatillisen toiminnan historian suuntaan. Tämä ei kuitenkaan kerro ay-aktiivien näkökulman korostumisesta, sillä tarkastelutapa on säännönmukaisesti sisällöltään avarampi kuin perinteisessä järjestöhistoriassa. Huomionarvoista on kuitenkin poliittisen ryhmätoiminnan rajautuminen perinteisten ammattiosastohistoriikkien tavoin tutkivien kerhojen tarkastelemien teemojen ulkopuolelle. Se tuo esiin yhden työläisten ammattiyhdistystoimintaan liittyneen ajatusmuotojen ulottuvuuden. Työväenaatteellisuuden esiintuomista on pidetty itsestäänselvyytenä, mutta perinteisen politiikan yhteyttä käytännön ay-toimintaan ei ole tunnustettu - vaikka se maailman sivu on ollut kaikkien nähtävillä. Tärkeä tutkiviin kerhoihin liittyvä piirre on myös työn historian osuuden jääminen vähäisemmäksi kuin alkuvaiheen tutkimussuunnitelmat antoivat odottaa. Tämä on ilmeisesti liitettävissä kahteen Paperiliitolle ominaiseen piirteeseen. Työ ja nimenomaan sen sisältö on ensinnäkin tutkimuskohteena aivan yhtä ongelmallinen kuin mitä se on erittelevän keskustelun aiheena. Toiseksi edunvalvonta ja ammattiosaston muu toiminta nähdään varsin pitkälle toisistaan erillisinä kokonaisuuksina, jolloin tutkiva kerho mielletään yhdeksi tuon muun toiminnan muodoista. Tämä on silmiinpistävin ero Paperiliiton ja Pankkitoimihenkilöliiton välillä, jossa pääosa tutkivista kerhoista eri tavoin penutuu työn muuttumisen ja edunvalvonnan suhteeseen. Ero kertoneekin ennen muuta peritneisten ajatusmuotojen sitkeydestä SAK:n liitoissa.

Tutkivien kerhojen työskentely lähtee liikkeelle 1980-luvun todellisuudesta. Useiden tutkimuskohteena on lisäksi aivan tuore menneisyys ja joillain on tavoitteena tuottaa tietoa ajankohtaisen ammatillisen toiminnan perus- 
taksi. Mistään itseisarvoisesta mennesiyyden tutkimisesta ei Paperiliiton historiahankkeessa siten ole kyse. Silti monilla mukana olevista samanlainen nostalginen perusvire kuin yleensä paperiliittolaisaktiiveilla. Aatteellisuuden näkökulmasta tilanne oli "ennen" myönteisempi, vaikka olot muutoin olivatkin ankeammat. Tässä tulee esiin yksi keskeisistä työväenliikkeen kriisin ulottuvuuksista. Perusjärjestöjen aktiivit pitävät työväenliikettä välttämättömänä, mutta eivät löydä sen olemassaoloa oikeuttavia perusteita muualta kuin menneisyydestä. Mutta nostalgisuus kertoo muustakin. Suomesta puuttuu yhteiskunnallinen liike, joka yhdistäisi omassa käytännön toiminnassaan kahdeksankymmentäluvun palkkatyöläisyyden vielä 1950-luvulla elävänä välittyneeseen työväen omaan perinteeseen.

\section{Kyse on ihmisen oikeudesta ajatella}

Paperiliitto on ottanut muutamia askeleita näkökulman avaamiseksi toisenlaiseen tulevaisuuteen. Samalla tiellä jatkaminen edellyttää ensinnäkin ammatillisen ja poliittisen työväenliikkeen välisen suhteen uudelleenarviointia. Sekä välttämättämyys arvioida uudelleen oma järjestöluonne että vaihtoehdon kehittäminen "omillaan toimeentulemisen" elämäntavalle vaativat siitä totutusta ajatusmuodosta luopumista, jossa ay-toiminta määritetään peruslähtökohdaltaan puolıstustaistelun luonteiseksi. Yhteiskuntakehityksen perusteisiin vaikuttaminen ei enää voi jäädä yksin vasemmistopuolueiden tehtäväksi.

Mutta Paperiliitto on myös lähtenyt kehittämään jäsentensä toimintakykyä tavalla, joka nostaa esiin kysymyksen inhimilliseen yhteiskuntaan tähtäävän strategian vatiman tieodn tuottamisesta. Kyse ei ole pelkästään siitä, että totuttu välittömiin toiminta- ja neuvottelutilanteisiin liittyvä tiedonhakinta on käynyt riittämättömäksi jopa ammattiliitolle. Ongelman laajakantoisuutta kuvaa se, että Paperiliiton historiahanke ja valistusprojekti ovat tosiasiallisesti kokonaan uudenlaisen tutkimuspoliittisen keskustelun avaus. Sen kohteena on ihmisten oman toiminnan ja tieteellisen tutkimuksen suhde. Tämän keskustelun perustelu taas nousee myöhäiskapitalistisen yhteiskunnan luonteesta. Tieteentekijä voi antaa oman panoksensa inhimillisen yhteiskunnan rakentamiselle vasta, kun hän on määrittänyt suhteensa ihmisen mahdollisuuksiin kehittää omaa itsetiedostustaan ja toimintakykyään.

Perustavanlaatuisin keskustelun teema liittyy tiedon muuttuneeseen yhteiskunnalliseen luonteeseen, mikä näkyy mm. siinä, että ihmisestä on tulossa tiedonkin osalta ohjelmoitu kuluttaja. Hänellä on kyllä monin verroin vanhempiaan paremmat mahdollisuudet saada tietoa, mutta hänen ei tarvitse ajatella yhtä paljon kuin nämä. Ihmiselle välittyvä tieto on koko ajan kaventunut ja tiivistynyt sisällöltään, se saadaan yhä "valmiimpana". Myös koulutus on alkanut kehittyä valmiiksi kootun ja jäsennellyn tiedon, tietopakettien välittämisen suuntaan. Teknologinen kehitys vaatii tietojen ja tietojenkäsittelyn standardisoimista ja on tehnyt tiedon tuottamisesta teollisuutta. Tietorekisterit ja tietopankit kertovat siitä, että tiedostakin on jo tullut tavara, jota mainostetaan, myydään ja ostetaan. Kaupallistunut tiedon tuottaminen ja tiedon välitys ovat myös keskityneet. Tiedosta on kokonaan uudella tavalla tullut vallankäytön väline. Kehitys kulkee kohti yhteiskuntaa, jossa ihminen luulee ajattelevansa, mutta joutuu tosiasiallisesti ajattelemaan toisten valmiiksi ajattelemalla tavalla. Mutta samanaikaisesti ollaan myös siirtymässä uudenlaiseen, tietotyöhön pohjaavaan tuotantoon, joka vaatii työntekijöiltä nimenomaan itsenäistä ajattelua. Tämän ristiriidan ratkaiseminen tavalla, joka ei silvo ihmisen ajattelua, on myös ammattiyhdistysliikkeelle asettunut haaste.

Ihmisen oikeudesta ajatella on joka tapauksessa tullut keskeinen luokkataistelukysymys. Tästä yleisestä näkökulmasta on tarkasteltava ihmisen mahdollisuuksia kehittää omaa tietämystään ja omaa ajatteluaan, hänen itsetiedostustaan. Voidaan kysyä, riittävätkö siihen enää totutut opiskelun ja itseopiskelun muodot. Riittääkö sen perustaksi enää tiedonhankinta, vai onko edettävä omakohtaiseen tiedon tuottamiseen saakka? Tutkiva opintokerho on joka tapauksessa yksi niistä muodoista, joissa taistelu ajattelemisen oikeuden puolesta tapahtuu. Paperiliiton historiahankkeen myötä on myös avautunut näköaloja hyvinkin syvälle menevään itsetiedostukseen. Sellainen sisältyy esimerkiksi mahdollisuuteen kehittää muistitiedon pohjalta menetelmiä oman ajattelutavan yhteisöllisen ja yhteiskunnallisen määräytyneisyyden tutkimiseksi. Tätä tietä tarjoutuu myös mahdollisuus päästä kiinni niihin ajattelutapojen rakenteisiin, joilla ihmistä myöhäiskapitalistisessa yhteiskunnassa alistetaan ja voittaa ne. Mutta samaa lähestymistapaa paperiliittolaiset voivat soveltaa myös vastatessaan valistusporjektinsa työkirjassa keskeiseksi välittömäksi tavoitteeksi asetettuun haasteeseen. "Meidän ay-aktiivien on opittava ymmärtämään, miksi suuri enemmistö ajattelee ja toimii siten kuin tekee."

Tutkivan kerhon tavoitteiden ei toki tarvitse olla näin kunnianhimoisia. Kyseessähän on ennen muuta yleinen kollektiivisen itsetiedostuksen ja tiedon tuottamisen muoto, jota Paperiliitto on tehnyt tunnetuksi Suomessa. Sen 
kokemuksia edelleen kehittäen on TVK:hon kuuluva Pankkitoimihenkilöliitto panostanut tutkiviin kerhoihin omia toiminnallisia tavoitteita hahmottaessaan. Kun esimerkiksi pyritään tuottamaan työn sisällön ongelmiin liittyvää tietoa, tutkiva kerho onkin kahdessa suhteessa ammattitutkijan palkkaamista tarkoituksenmukaisempi ratkaisu. Tutkimuksen tekijöillä on ensinnäkin kokonaan toiset edellytykset lähestyä tutkimuskohdetta työntekijän näkökulmasta, sillä työtä tutkittaessa on asiantuntija sitä tekevä ihminen. Myös tutkimustulokset saadaan välittömämmin hyödynnetyksi, koska tutkimusprosessi voidaan suunnitella kaikissa vaiheissaan käytännön toimintaa palvelevaksi. Sekä Paperiliiton että Pankkitoimihenkilöliiton kokemukset osoittavat, ettei tutkimustyön edellyttämän koulutuksen järjestäminen ole ylivoimainen ongelma.

Paperiliitto ja Pankkitoimihenkilöliitto ovat Suomessa toteuttaneet käytännössä sen vaatimuksen, jonka SAK:n ruotsalainen veljesjärjestö, LO asetti vuonna 1981: "tutkimuksen on saatava uusi paikka, uusi tehtävä. Enää ei saa työläisiä panna tukemaan tutkimusprojekteja. Työläisten on saatava itse - esimerkiksi opintokerhossa ammattiliiton piirissä - harjoittaa omaa tutkimusta ja heidän on saatava käyttää apuna tutkijoita ja asiantuntijoita." Tämä peruslähtökohta ei kuitenkaan sellaisenaan riitä ratkaisemaan työväenliikkeen suhdetta tutkimuksen harjoittamiseen.

Vaikka onkin ollut oikeutettua murtaa ammattilaisten yksinoikeus tutkimuksen tekemi- seen, tieteen olemassaolon oikeuden kieltämiseen ei ole perusteita. Tämä tarkoittaa ensinnäkin sitä, että myös ei-ammattilaisten tutkimustyössä on noudatettava tieteellisen työskentelyn perusperiaatteita. Jos näin ei menetellä, menetetään mahdollisuus kestävän tiedon saavuttamiseen ja ajaudutaan helposti vahvistamaan omia ennakkokäsityksiä niiden kriittisen arvioinnin sijasta. Toiseksi ei ole tarkoituksenmukaista sälyttää kaikkea tutkimusta työläisille ja siksi on sovittava ammattilaisten ja ei-ammattilaisten työnjaosta.

Rakentavan suhteen määrittäminen ei-ammattilaisten tutkimustyöhön edellyttää ammattilaisilta sen keskeisen tutkimusta koskevan peruslähtökohdan hylkäämistä, jossa tutkimus ja ihmisen toiminta erillisestetään toisistaan. Tätä peruslähtökohtaa ei myöskään ylitä ns. toimintatutkimus, josta SAK:n elämäntapakurssikokeilu on ollut yksi osoitus. Toimintatutkimus on kyllä askel oikeaan suuntaan, koska siinä pyritään synnyttämään ja edistämään ihmisten omaa toimintaa. Heillä on myös mahdollisuus vaikuttaa tutkimuksen etenemiseen, mutta sen lähtökohdista ja tavoitteista päättää ja varsinaisen tutkimustyön suorittaa silti ammattitutkija. Toimintatutkimuksessakin alistuvat siten ihmisten omasta todellisuudestaan käsin nostamat vaatimukset tieteen sisäisille näkökohdille.

Artikkelin pohjana on Näkökulmia tulévaisuuteen. Paperiliiton historia 1944-1986. Paperiliitto 1986. 